\title{
FOLLOWING THE TRACES OF SERBS THROUGH NORTHERN ITALY
}

\section{Radmila Mihajlović}

RAl,

Rome, Italy
Correspondence:

Radmila Mihajlović

e-mail:

mila.mihajlovic@gmail.com

\section{Abstract:}

Since bygone times Italy has been one of the most attractive destinations of Serbian emigrants. We find Serbian cultural monuments across the Apennine peninsula. They are a testimony to the continual connections and presence of Serbs in this region. Traces of Serbian culture in Italy date from various periods of time. Italian historiography registered seven Serbian migrations to Italy only during the 15th century. In the first years of the 11th century Italian documents mention Castle Belgrade and Serbian villages in the area of today's Italian region of Friuli-Venezia Giulia. In response to the call of the Bishop of Aquileia, it is known that Serbs emigrated to Northern Italy at the end of the 9th and the beginning of the 10th century when they settled the empty areas following the havoc left behind by the Hungarian invasion (Vastata Hungarorum). From numerous documents of that period, it is known for certain that Serbs lived in that area even a few centuries earlier. Across Italy Serbs have left a cultural heritage of immeasurable historical value and universal cultural significance.

\section{Keywords:}

Italy, migrations, Serbian culture, Serbian cultural heritage, palaces, Castle Belgrade, icons, cult of Saint Petka, Serbian kings, churches

\section{INTRODUCTION}

Italy has always been one of the most attractive destinations of Serbian emigrants. Serbian cultural monuments found across the Apennine peninsula are evidence of the continual relations and presence of Serbs in this region. Traces of priceless historical and artistic value left by Serbs across Italy throughout the centuries are almost never mentioned as Serbian, nor are they connected with Serbia and Serbs, regardless of the still present and unmistakable indicators of their origin. This presentation of Serbian cultural heritage in Italy is organized in three territorial units: Friuli-Venezia Giulia, Veneto and Piedmont..

\section{FRIULI - VENEZIA GIULIA}

The most important place of Serbian cultural memory in Italy, specifically in Northern Italy, is the city of Trieste. By the beginning of the 18th century Serbs began to settle in greater numbers in Trieste 
attracted by a wide range of possibilities for business after the Austrian Emperor Charles VI proclaimed freedom of navigation on the Adriatic Sea and two years later proclaimed Trieste as a free port.

By 1753 the Serbs had already built their first church, Church of Saint Spyrudon, together with the Greeks. It was erected on the most expensive land in the city with financial aid from Empress Maria Theresa only two years after Empress Maria Theresa, in her imperial decree ${ }^{1}$ of 20 February 1751, proclaimed the right of Serbs to establish their church in Trieste with services in the Serbian language. It was in the vicinity of the Grand Canal (Canal Grande) at the place of the former salt mines, and very soon it started to sink. Therefore, the Serbs built a new one. Construction of the new church began in 1861 and the temple was officially opened 20 September 1869. Even today this Serbian church is the biggest and the most beautiful church in Trieste, one of the most beautiful Orthodox churches in the world and a cultural monument of universal value.

The first scholarly bibliography of Serbian books compiled in 1964 by medical doctor, Dr. Georgije Mihailović, for the first time introduced titles from the library of the Serbian Orthodox Church Congregation in Trieste. (Mihajlovic, 1964) From there it is known that in the period from 1701 to 1800 a total of 408 Serbian books were published, among which 28 are preserved in the Library of the Serbian Orthodox Church Congregation in Trieste. (Mitrovic, 2009) Those are the only existing samples, and thus a cultural treasure of priceless value. The treasure of this library is still not fully explored since the inventory of all books kept in three large halls of the Serbian Triestine library at the Square of Saint Antonio Nuovo no.7 has not been completed. The work is in progress thanks to the Archives of Serbia and the decision of the National Library of Serbia to enter into its electronic catalog the bibliographic data of all materials in the Serbian library in Trieste.

The business success of the Triestine Serbs evolved into ownership of real estate. During two centuries Triestine Serbs built or purchased about sixty buildings and palaces, many of which are still symbols of the city. We will mention only a few. The Palace of Count Jovo Vojnović included a big park, and by the end of the 19th century the City Zoo was located there. A building erected by the Kovačević family was the seat of the Catholic diocese for a period of time. State offices are now located in the Palace of Count Jovović, today's Pitteri Palace (Palazzo Pitteri) at Piazza dell'Unità, the main city square next to the City Hall. For seven years the House of Lazarović was the residence of Prince Maximilian Habsburg. In his last will Aleksandar Vukasović left to the Serbian Orthodox Church Congregation a building located at the Square of Saint Antonio with one of the oldest and most famous cafes in Trieste, the "Polar Star Café" (Café Stella Polare). The merchant Jovan Nikolić was the owner of a whole block of buildings right next to it. Nearby is the Palace Kurtović and the more modest three-storey Palace of Dragutin Teodorović where Dositej Obradović and Pavle Solarić once lived. Simeon Gopčević left a palace in Trieste which occupies the central part, the length of the whole district of Teresiano, and looks over the Grand Canal. On the façade of the four-storey building are four statues with the faces of Princess Milica, Prince Lazar, Miloš Obilić and the Kosovo Maiden. In 1833 and 1839 Petar II Petrović Njegoš stayed in the Ivanović Palace, the home of Count Matija Ivanović. Here is also the Škuljević Palace, the first seat of the Consulate of the Kingdom of Serbs, Croats and Slovenes, but also the magnificent Vučetić Palace, Palace of Jovanović, Rađenović, Bojović and many others. All of them still bear the names and memory of their first owners and builders.

In 1772 Empress Maria Theresa gave permission to the Serbs and Greeks to establish their own cemetery. In 1785 Triestine Serbs purchased land in a part of the city called Barriera Vecchia, moved their cemetery there and built the cemetery chapel. (Medakovic \& Milosevic, 1987) One century later, due to urban expansion of the city and Napoleon's laws, the Serbian Orthodox Church Congregation was compelled to move it again. For that purpose, they bought land on the street Via della Pace. In 1825 next to the cemetery they built a chapel dedicated to Saint George and an impressive entrance gate. (Medakovic \& Milosevic, 1987)

Four Serbian saints lived in Belgrade on Varmo (Udine) in the Friuli region. In this area, in the Varmo River valley, the Bishops of Aquileia invited Serbs to this region following the havoc left behind by the Hungarian invasion (Vastata Hungarorum) at the end of the 9th and the beginning of the 10th century (Errante Parrino, 2005). Together with numerous Serbian toponyms, the Castle Belgrade on Varmo and the town with the same name were mentioned in a document dated 1001 in which Emperor Otto III donated them to Patriarch John IV. (Belloni, 1980) (Il Medioevo, a cura di Cesare Scalon, 2006) Based on numerous documents of that period it is known for certain that Serbs lived in that area even a few centuries earlier. (Buccaro, 2015 ) (Savorgnan, 2015) That is why this territory is called "Slavic villages" (Ville Slavorum).

1 Patente di riconoscimento (Patent on tolerance). 
Around 1465 Countess Katarina of Celje, daughter of Despot Đurađ Branković and sister of Despot Stefan the Blind ${ }^{2}$, bought the town of Belgrade on Varmo together with the entire estate and all accompanying rights and privileges. Despot Stefan was dethroned and on 8 April 1459 he had to leave Smederevo and go into exile which lasted to his dying day. Castle Belgrade with its auxiliary buildings, the Church of Saint Nicholas and the mill should have become the new home for Despot Stefan and his family. ${ }^{3}$ The fief included the villages of Belgrade, Saint Marica, Gorica, Goričica and Gradište which still exist as toponyms. It soon developed into the fortified town of Belgrade, and the Castle Belgrade became the center of an articulated system of fortified castles. It had exceptional strategic importance since all crossings over the river Tagliamento and communications between the important river ports of Latisana and Stradalta were controlled from it.

Despot Stefan the Blind lived very modestly in the Castle Belgrade. The castle maintenance and staff costs were much higher than the feudal revenues, despite the financial aid he was receiving from Dubrovnik and Venice. The fact that Venice had its ambassador at the court of Despot Stefan was evidence of the importance of Belgrade on Varmo. It is known that Despot Stefan had a personal secretary and that he had brought the family library from Smederevo. Despot Stefan the Blind, the last anointed and legitimate Serbian despot, died in Belgrade on Varmo on 9 October 1476. He was buried in the Church of Saint Nicholas which does not exist anymore. In a later period, a former church dedicated to the Mother of God used to be mentioned in Belgrade on Varmo, but it also disappeared.

Without a means of livelihood, eight years after her husband's death, in 1484 Despotess Angelina had to leave Belgrade with her children and seek refuge in Vienna thanks to Emperor Frederick III Habsburg. In those years the invasion by the Turks of Mehmed II the Conqueror had devastated the valley of the river Soča. Whenever Despotess Angelina was away the town was guarded by a Serbian garrison under the command of Captain Đorde Grebeljan. It is an interesting detail that Despotess Angelina asked the Count of Gorica, the former owner, to re-purchase the castle, since Captain Grebeljan did not want to surrender the town to any buyer who was sent by the sultan.

In 1485 Despotess Angelina mortgaged Belgrade in favor of former Byzantine nobleman Matteo Spandugino, who was in the service of the Habsburg Court, as a guarantee for the loan for the dowry of her daughter Mara who was marrying the Count of Montferrat, Boniface III, descendant of Theodor, son of Emperor Andronicus Palaeologus and Irina of Montferrat. In the same year Despot Vuk Branković ${ }^{4}$ died, and in 1486 Hungarian King Matthias Corvinus placed Đorđe the older son of Despotess Angelina on the throne of the Serbian Despotate. As a result of that, the whole family moved to Hungary. Castle Belgrade was already mortgaged and there was no hope that they could return it. Despotess Angelina transferred the body of Despot Stefan to a new burial place; he had rested in Belgrade on Varmo for more than ten years, and she buried him in Kupinik, in the Church of Saint Luke.

2 Katarina Branković (1418/1420-1491/1492) was the younger daughter of Despot Đurađ and Irina Kantakouzene, the daughter of Theodor Kantakouzene and granddaughter of the Byzantine Emperor John VI. She was married on 20 April 1434 to the German Ulrich II, Count of Celje. It was a political marriage that was intended to provide Western support to the Serbian Despotate. Her sister Mara was married to Murad II in order to provide protection from the East. Katarina gave birth to three children who all died early. She was very educated and respected: She ordered the "Varaždin Apostol", a handwritten Serbian Orthodox liturgical book written by three scribes in 1453 or 1454. It is also the oldest preserved Cyrillic manuscript from the territory of today's Croatia. Pope Pius II said once of Katarina of Celje that she is "beautiful and honest". Together with her sister, Sultana Mara, she facilitated the conclusion of the Treaty of Constantinople after the Ottoman-Venetian war. After Mara's death, she took care of the monasteries on Mount Athos. She died in 1492 in the village of Konče where she was buried in the local Church of Saint Stefan. The Serbian Orthodox Secondary School in Zagreb was named after her, and the Metropolitanate of Zagreb-Ljubljana grants the Order of Kantakouzene Katarina Branković. It is considered that her endowment is the Monastery Rmanj in Martin-Brod where the Unac flows into the river Una.

3 Saint Stefan the Blind, Serbian Despot (1417-1476) was the son of Đurađ Branković (son of Mara, the oldest daughter of Prince Lazar and Princess Milica, married to Vuk Branković) and the Byzantine Empress Irina Kantakouzene. Since Despot Stefan Lazarević (1389/1393-1402/1427) did not have male descendants, the throne shifted to the collateral line, to Despot Đurad Branković who ruled from 1427 to 1456. Despot Đurađ married two times and he had three daughters: Mara who was married to Murad II, Katarina married to Ulrich of Celje, and Jelena, and four sons: Teodor, Grgur, Stefan and Lazar. For political reasons, Murad II captured Grgur and Stefan and blinded them. After the death of Despot Đurad, he was succeeded by his youngest son Lazar. Despot Lazar Branković died on 20 January 1458 and was succeeded by his older brother, Stefan the Blind. Enthroned and anointed in Smederevo with the blessing of the Serbian Patriarch, he was the last anointed, legitimate Serbian Despot. During his short rule (until 1 April 1459 when he was dethroned), he gained the respect and admiration of the people because he did not surrender Smederevo to the Turks or Hungarians. Expelled from Serbia, he went via Croatia to Dubrovnik and on to Albania where he married Angelina, sister-in-law of Đurađ Castriot Skanderbeg. He had three children with her: Mara, Đorđe, and Jovan.

4 Vuk Branković (1440-1485), Serbian Despot from 1471 until his death, known among Serbian people as the Dragon Vuk, son of blind Grgur Branković, brother of Despot Stefan the Blind. 
As an important strategic location, Belgrade on Varmo would shift many times from the hands of the Habsburgs to the hands of Venice and vice versa. Finally, in 1515 it would belong to Venice. Venice would donate the estate to the nobleman Girolamo Savorgnan as a sign of gratitude for the defense of the town of Osoppo from the Austrians.

Four Serbian saints lived in Belgrade on the river Varmo: Saint Stefan the Blind (celebrated October 22), Venerable Mother Angelina (celebrated August 12), Saint Maximus, Serbian Archbishop (celebrated January 31) and Saint Jovan, Serbian Despot (celebrated December 23). Near Udine, the town of Belgrade merged into the town of Varmo long ago, and there is still Belgrade Street, Castle Street, Gradište Street, Saint Vid Street (Vidovdanska). Of the ancient Castle Belgrade only a tower remained, and it was transferred to the church bell tower.

The name of the noble family Deciani is closely related to the city of Udine, which undoubtedly points to a connection of this area with Serbia. Tiberio Deciani (1509-1582) is considered one of the fathers of modern Italian criminal law. His father Nicola was working in Udine as a scribe between 1426 and 1482. Tiberio would become a famous Venetian lawyer, a professor and legal advisor of the Republic of Venice. In the historiography of legal studies, his work "Tractatus Criminalis" is considered the first declaration of modern Italian law which signifies a turning point in legal practice. (Deciani, 1590) He received the title of Count of the Knight of Saint George in 1578 from the heir of the Byzantine royal family of Komnenos and in the same year the noble title of Knight of Saint Mark from the Republic of Venice. One street in Udine is named after him.

Tiberio Deciani was very rich, and near his native town of Martignacco he built his summer residence, Villa Deciani. Even today the family summer residence is a cultural monument of the town of Martignacco located on the street named after him. Tiberio Deciani purchased it around 1550 and converted it into a palace. The 14th century Church of Saint Nicholas was already on the palace property. Its historical importance is such, that it occupies the larger part of the coat of arms of the Municipality of Martignacco.

The small town of Martignacco in the district of Udine is connected to Serbia through another palace and events from recent history - the Villa Italia which, during the First World War, was the residence of Italian King Vittorio Emanuele III who had moved there at the beginning of the war. Queen Jelena Petrović of Savoy came to the Villa often. In March 1916 Prince Regent Aleksandar I Karađorđević, Nikola Pašić, Slobodan Jovanović and other members of the Serbian Government stayed in the Villa.

At Patriarchate Square (Piazza Patriarcato), the former seat of the Patriarch of Aquileia next to the Archbishop's Palace, is the Belgrade Palace (Palazzo Belgrado). Built in 1545 by powerful noble family Antonioni, it remained in their ownership until 1807 when it was transferred to the ownership of the noble family Belgrado through the marriage of Margherita Antonioni, the last offspring of the family, to Baron Horatio of Belgrade. From then, the palace changed its name from Palazzo Antonioni to Palazzo Belgrado. Some important persons stayed there: Pope Pius in 1782; Franz II Habsburg in 1816, 1819 and 1825; Napoleon Bonaparte in 1797 and 1807; Vittorio Emanuele III of Savoy and Queen Jelena on 23 August 1903. Since 1891 the palace is the seat of the District of Udine. It is interesting that there was another noble family named Belgrado which lived in Udine, but those two families were not related. Maintaining the Integrity of the Specifications

\section{VENETO}

The first significant Serbian connection with Venice was the marriage of Anna Dandolo, granddaughter of the famous Doge of Venice, Enrico Dandolo, to Serbian King Stefan the First-Crowned in 1217. Together with him she gave birth to sons Predislav, the latter Archbishop Sava II, and Serbian King Stefan Uroš I. The marriage of Anna Dandolo and the Grand Prince of Serbia and Srem took place in Venice, and the newlyweds sailed from Venice on the large state galley Moceniga, through Dalmatia to Serbia. Stefan Nemanjić agreed with the Roman Pope Honorius III that he recognize him as the King of Raška, since papal recognition meant international recognition of Raška as an independent state. In the same year, the papal legate arrived in Serbia and performed the coronation. 
Stefan Nemanjić was named "The First-Crowned", as the first Serbian King with a crown, and Raška became a kingdom in $1217 .{ }^{5}$

Serbs have left many traces of their presence in Venice starting in 1420 when the largest part of Boka Kotorska came under Venetian rule. Their contribution in all spheres of life in the Republic of Venice lasted until the end of 1797 when Venice disappeared from the historical scene. Riva de Schiavoni, part of the coast reserved for loading and unloading of their ships, also testifies to their influence, as well as the street Calla Zaguri, named after the well-known noble family Zagurević from Kotor. There is also the Palace of the Ivanović family from Dobrota and the tomb built in the Church of San Giovanni Bragora by the seaman and warrior Vicko Bujović for his brother Ivan and the captains of Perast.

The Church of Fraternity of Saints George and Tryphon, also known as the School of Saints George and Tryphon or the Schiavoni School. ${ }^{6}$ is also a significant monument of Serbian culture. It was founded at a gathering of 200 prominent seamen from Boka and Dalmatia on 24 March 1451 in a hall of the Hospital of Saint Katarina. Its former location used to be at a small Renaissance palace in the Sestiere Castello district, near the Riva de Schiavoni next to the bridge Ponte della Commenda.

In the period between 1563 and 1832, when the state printing house in Serbia started working, Venice was the home of Serbian printing. From the first decades of the 16th century, Serbian books were printed in Venetian Cyrillic printing shops: first in the printing house of Božidar Vuković (1520-1540), and then in the printing house of Pane Teodosije. In the second half of the 18th century the printing of Serbian Cyrillic books in this city reached its peak. The first poetic work of Serbs was printed in Venice, the first Serbian alphabet book, the first Serbian magazine, the first monograph in Serbian - the beginning of a Serbian historical novel , the books of Pavle Solarić " "Ethics" and "Vostani Serbije" 9 of Dositej Obradović, and many other books, Serbian textbooks and other texts of a religious and secular nature. (Orfelin, 1950) (Orfelin, 1766) (Orfelin, 1772) Between 1761 and 1776 about fifty "Servian" books were published in this printing house. (Fin , 1982)

The town of Jesolo is part of the territory of Metropolitan Venice and one of the leading tourist localities in Italy. Since 26 July 2009 there is a street in it named after the Serb Dragan Cigan. On 22 July 2007 he drowned in the water of the swollen Piave River trying to save two Italian children. The then President of the Republic of Italy, Giorgio Napolitano, decorated him posthumously with the highest Italian state decoration, the Gold Medal for civilian service, and the town of Jesolo named a street after the hero Dragan Cigan.

\section{PIEDMONT}

The Marian Sanctuary of Vicoforte, which was proclaimed in 1880 as an Italian monument of national importance, includes a basilica and five chapels. In one of them, in the Chapel of Saint Bernard next to Duke Charles Emanuel I, the Italian Queen Jelena Petrović Njegoš or Elena of Savoy has been resting since 15 December 2017. ${ }^{10}$ Two days later, 70 years after his death, the body of her husband Vittorio Emmanuel III, the penultimate King of Italy, was laid to rest next to her. ${ }^{11}$

5 Andreae Danduli, Chronica per extensum descripta, Venezia, aa.46-1280, 1352, ristampa a cura di Ester Pastorello, Bologna: Zanichelli, 1958; Thomas Archidiaconus, Historia Salonitana, Split: 1266. Thomas Archidiaconus (1200-1268) was a chronicler from Split who recorded the historical events of his town and the whole state (Republic of Venice), including certainly the coronation of Grand Serbian Prince. He also recorded that at the time of preparations of the Hungarian King Andrew Arpad for the Crusade in the Holy Land, Prince Stefan, the Lord of Serbia and Raška, had sent some reputable envoys to the Holy See to ask Pope Honorius III for the royal crown for himself. He also recorded that Stefan's wife Anna also received the crown, and that it happened right after their wedding.

6 Schiavoni is the term used in the early medieval Apennine Peninsula to identify the Slavs. In the Republic of Venice the term Schiavoni was used later also as a geographic term for the entire coast of Istria, Dalmatia and Boka Kotorska, and the name Schiavoni was used for all of those coming from those regions.

7 Ново гражданстко земљеописаније“ (New civil geography) was printed in 1804 and represents the first geography book written in Serbian, the document of Adam Christian Gaspari translated by Solarić from German

8 „Славеносербски магазин (Slav-Serbian Magazine), Захарије Орфелин, 1768. It was the first Serbian secular, civic and educational book

9 "Ethics" was printed in 1803, and "Vostani Serbije" was written in Trieste in the fall of 1804. Dositej printed it in 20 copies at his own expense in the printing house of Pane Teodosije in Venice

10 Jelena of Montenegro or Elena of Savoy (1873-1952), the penultimate Queen of Italy.

11 Vittorio Emmanuel III of Savoy (1869-1947) the penultimate King of Italy and husband of Jelena of Montenegro 


\section{CONCLUSION}

Since the beginning of the common state of Serbs, Croats and Slovenes Serbian cultural heritage in Italy was forgotten. It was deleted from the historical memory of the mainstream and left to unavoidable assimilation, merging into foreign cultural heritage. This is why the renewal and affirmation of the huge Serbian cultural heritage in Italy is the first task. This is especially true under the circumstances of the large inflow of new waves of Serbian immigrants to Italy who represent the most important life resource for preserving Serbian cultural values outside the borders of the homeland.

On the other hand, the affirmation of Serbian cultural heritage in Italy opens the doors for the development of ethnic tourism in this country with great economic and political possibilities for the development of economic partnership in the fields of tourism and culture in both countries. All of it has added value, considering the fact that tourism is one of the pillars of the Italian economy and that half of the total world cultural heritage is located in this country. ${ }^{12}$

\section{REFERENCES}

Belloni, A. (1980). Vitae partiarcharum Aquilejensium . Bologna: Forni.

Buccaro, D. (2015). Belgrado "dei sette castelli". Udine.

Deciani, T. (1590). Tractatus criminalis. Venezia.

Errante Parrino, S. (2005). Ortodossi a Belgrado di Varmo per Kantakuzina. Messaggero Veneto.

Fin, M. (1982). I libri serbi e Venezia . Padova : Kiev-Buda-Venezia:i centri di sviluppo della cultura serba nel Settecento.

Il Medioevo, a cura di Cesare Scalon . (2006). Udine: Forum.

Medakovic, D., \& Milosevic, D. (1987). Chronicles of Serbs in Trieste. Yugoslavian Review, 124.

Mihajlović, G. (1964). Srpska bibliografija XVIII veka. Beograd: Narodna biblioteka Srbije. In Serbian.

Mitrovic, M. (2009). La biblioteca della comunità serbo-ortodossa nel contesto culturale serbo. Trieste: Silvana Editoriale.

Orfelin, Z. (1950). Plač Serbiji. Novi Sad: Matica Srpska.

Orfelin, Z. (1766). Latinski bukvar. Venecija: Tipografija Dimitrija Teodosija.

Orfelin, Z. (1772). Žitije Petra Velikog. Venecija: Tipografija Dimitrija Teodosija.

Savorgnan. (2015). Progetto Integrato Cultura del Medio Friuli.

12 According statistics from 2015, tourism contributed to the gross domestic product of Italy with $11.8 \%$ or with 171 billion Euros, with over 3.1 million employees. Besides, on the UNESCO list of world cultural heritage for 2018, Italy is in first place with 54 monuments of culture. 